\title{
Das enzimas à análise sensorial: relato de aula prática interdisciplinar
}

\author{
Enzymes to sensory analysis: report of interdisciplinary practice session
}

\author{
Durinézio José de Almeida ${ }^{1 *}$, Renata Demario ${ }^{2}$, Guilherme Barroso ${ }^{3}$ \\ ${ }^{1}$ Doutorando em Biologia Comparada, Universidade Estadual de Maringá - UEM; Docente, Faculdade \\ Campo Real. \\ ${ }^{2}$ Docente Departamento de Nutrição, Universidade Estadual do Centro Oeste do Paraná - Unicentro. \\ ${ }^{3}$ Docente Departamento de Farmácia, Universidade Estadual do Centro Oeste do Paraná - Unicentro \\ *e-mail: durinezio@gmail.com
}

\section{Resumo:}

Em programas acadêmicos de Nutrição, a Bioquímica é uma das disciplinas iniciais, contudo fundamental para o decorrer do aprofundamento no curso. Esta disciplina engloba aulas práticas com o objetivo de melhorar a compreensão e tornar mais eficaz o entendimento do conteúdo, pois são baseadas em observações diretas elucidando reações moleculares das quais tange o ensino da disciplina de Bioquímica.O texto pretende expor a experiência de uma aula prática multidisciplinar como contexto inicial as enzimas e, que abrange noções das disciplinas de Análise Sensorial, Estatística, Biologia Celular e Tecnologias em Nutrição. A experiência mostrou-se frutífera e efetiva demonstrando que a pedagogia da redescoberta é importante em disciplinas em que é exigido um grande nível de abstração dos alunos, como é o caso da Bioquímica.

Palavras-chave: Aula prática, Interdisciplinaridade, Bioquímica.

\begin{abstract}
:
In the academic programs of Nutrition, Biochemistry is one of the early disciplines, despite of that it is essential. This course includes practical classes in order to improve understanding and make more effective the teaching content, because it are based on direct observations which can elucidate the molecular reactions that teaching Biochemistry depends. This paper main to present the experience of an interdisciplinary practical class based in enzymes, which includes notions of the disciplines of Sensory analysis, Statistics, Cell biology and Technology in nutrition. The experience proved to be useful and effective, showing that pedagogy of rediscovery is important in disciplines in which required a high level of abstraction of students, e.g. Biochemistry.
\end{abstract}

Keywords: Practical classes, Interdisciplinary, Biochemistry. 


\section{Ficha da atividade desenvolvida}

Título: Das enzimas à análise sensorial: relato de aula prática interdisciplinar

Público alvo: Acadêmicos do Curso de Nutrição.

Disciplinas relacionadas: Bioquímica, Análise Sensorial, Estatística, Biologia Celular e Tecnologias em Nutrição.

Objetivos educacionais: Incorporação do conhecimento sobre enzimas proteolíticas por acadêmicos do Curso de Nutrição.

Justificativa de uso: Nos programas acadêmicos de Nutrição a Bioquímica é uma das disciplinas iniciais, porém fundamental ao curso. Esta disciplina engloba aulas práticas com o intuito de melhorar a compreensão e tornar mais eficaz o entendimento do conteúdo, pois são baseadas em observações diretas que elucidam as reações moleculares de que depende o ensino de Bioquímica.

Conteúdos trabalhados: Enzimas, Análise sensorial, Estatística, Tecido muscular. 


\section{Introdução}

A Bioquímica é uma ciência que vem mostrando progressos significativos, tornando cada vez mais complexo o desafio de manter-se atualizado [1-2]. Trata-se de uma disciplina que requer conhecimentos interdisciplinares o que permite a troca de conteúdos entre as mais diversas áreas, i.e. A fim de entender processos patológicos, farmacológicos, fisiológicos, de Biologia Celular, até mesmo interações entre ligantes e biomacromoléculas (responsáveis por muitas respostas sensoriais como calor, ardência, paladar e olfato) é necessário o conhecimento de processos bioquímicos [3-4]. Neste sentido, Murray e colaboradores [5] destacaram que a Nutrição e a Bioquímica estão associadas no estudo das substâncias que ingerimos, e que uma alimentação adequada depende essencialmente do conhecimento da Bioquímica.

Portanto, como as reações são comumente explicadas a nível molecular, a Bioquímica torna-se suporte subsunçor de conhecimento de várias disciplinas dela dependentes. No prefácio do livro Fundamentos da Bioquímica, Voet e colaboradores [6] relatam a necessidade de que os professores de Bioquímica estejam afinados com os anseios dos estudantes e, embora seja difícil a percepção das aspirações individuais de cada aluno, existem algumas que são inerentes ao ensino. Assim sendo, torna-se perceptível que "o ensino que castra a curiosidade do educando em nome da eficácia da memorização mecânica do ensino dos conteúdos é inautêntico, com vocábulos vazios e inoperantes e, evitar tal ensino, só é possível tendo como base os conhecimentos adquiridos por meio de experiências realizadas" [7].

A fim de investigar processos bioquímicos de uma maneira técnica e didática, torna-se necessário o emprego de instrumentos sofisticados, pois as moléculas não são percebidas pelos sentidos humanos [5-6]. Portanto, fica evidente uma dualidade composta da necessidade do aluno de observar e de interagir com o objeto de estudo, e da incapacidade, puramente pela abstração de fazê-lo.

Normalmente a disciplina é definida pelos estudantes como uma coleção de estruturas químicas e reações, difíceis de serem decodificadas. Esse pensamento dificulta o aprendizado, com isso, emerge a importância do desenvolvimento de modelos de ensino com o propósito específico de ajudar os alunos a entenderem os modelos consensuais, originando aulas mais dinâmicas. Neste contexto, atividades práticas em laboratório são as formas mais eficazes de demonstração e fixação do conteúdo, pois são 
baseadas em observações diretas que esclarecem as reações moleculares, propiciando experiências que permitam ao aluno à fixação do conhecimento.

A pedagogia da redescoberta busca formar o cidadão e preparar o trabalhador através da vivência do método científico. O conhecimento é o resultado direto da experiência. A metodologia é investigativa e experimental, envolvendo atividades com os alunos, onde esses imitam o trabalho dos cientistas, através de roteiros passo-a-passo, buscando alcançar os resultados e conclusões definidos pelo Professor. [8].

Diante do exposto, nota-se a existência de um direcionamento à formação de pesquisadores nesta linha pedagógica, cujo objetivo final é a descoberta por parte do aluno, sobre o qual a ciência já postulou e aceitou como correto. Neste texto pretende-se expor a experiência de uma aula prática, utilizando enzimas com as quais foi utilizada a abordagem da pedagogia da redescoberta, tratada de maneira interdisciplinar, isto é, envolvendo conhecimentos de Análise Sensorial, Estatística, Biologia Celular e Tecnologias em Nutrição.

\section{Materiais e Métodos}

A prática foi realizada no laboratório de Técnica Dietética da Faculdade Campo Real, no município de Guarapuava, no Estado do Paraná, Brasil, com acadêmicos do $1^{\circ}$ período do curso de Nutrição com duração de quatro horas.

Os alunos foram questionados sobre a compreensão do conteúdo após a aula teórica e após a aula prática, e seus comentários foram anotados.

O teste laboratorial foi centrado na ação das enzimas proteolíticas, da família das bromelinas e das papaínas. As enzimas foram extraídas diretamente do fruto do mamoeiro (Carica papaya L.) e da inflorescência do abacaxi (Ananas comosus). Para avaliação da possível diferença de concentração tecido específica em cada um dos materiais, foram extraídas as enzimas de tecidos diferentes, casca e polpa. As enzimas foram testadas, quanto à ação proteolítica em medalhões de músculo bovino, e os resultados foram avaliados através de análise sensorial.

A análise estatística foi realizada por meio de testes estatísticos destinados a verificar se as diferenças entre as amostras eram representativas. 


\subsection{Protocolos seguidos pelos alunos}

\subsubsection{Experimento I}

No início do procedimento os alunos devem dividir-se em cinco grupos com no máximo 4 alunos, totalizando 20 participantes. Cada grupo recebeu suas respectivas instruções:

Pesar o medalhão de músculo anotando o peso;

- Para o grupo “1”, pesar o equivalente a $30 \%$ do peso do músculo em casca de mamão;

- Para o grupo "2", pesar o equivalente a 30\% do peso do medalhão em polpa do mamão;

- Para o grupo "3" pesar o equivalente a $30 \%$ do peso do medalhão em casca de abacaxi;

- Para o grupo "4" pesar o equivalente a $30 \%$ do peso do medalhão em poupa do abacaxi;

- Para o grupo "5" usar o amaciante comercial segundo, as recomendações do fabricante;

- Com exceção do grupo "5" (amaciante comercial) todos os grupos devem adicionar $10 \mathrm{ml}$ de água destilada e bater em liquidificador suas amostras até formar uma massa densa e homogênea;

- Adicionar ao medalhão de carne a amostra, e aguardar 20 minutos.

Obs. Proceder ao experimento dois enquanto aguarda o tempo supracitado.

\subsubsection{Experimento II}

Os alunos devem acompanhar o professor ao o laboratório de microscopia para observação da lâmina permanente de músculo estriado esquelético. O objetivo deste experimento é observar o tecido muscular estriado esquelético que apresenta, sob observação microscópica, faixas alternadas transversais, claras e escuras. Essa estriação resulta do arranjo regular de microfilamentos formados pelas proteínas actina e miosina, responsáveis pela contração muscular e, pela dureza característica dos músculos quando usados na alimentação. O entendimento de como é formado o músculo permite inferências da ação de enzimas proteolíticas sobre ele.

Os materiais utilizados na realização desta aula prática podem ser visualizados no Quadro 1. Vale ressaltar que se buscou o emprego de materiais de fácil acesso e custo reduzido, com isso, esta prática poderá ser expandida a locais de baixo desenvolvimento econômico. 
Das enzimas à análise sensorial: relato de aula prática interdisciplinar

Quadro 1. Materiais empregados na realização da aula prática.

\begin{tabular}{|l|l|c|}
\hline Materiais/equipamentos & Quantidades & Total \\
\hline Lâminas permanentes de músculo estriado & 2 por grupo & 10 \\
\hline Atlas de Histologia & 1 por grupo & 5 \\
\hline Microscópio óptico & 1 por grupo & 5 \\
\hline Óleo de imersão & $10 \mathrm{ml}$ & $10 \mathrm{ml}$ \\
\hline Mamão verde & 1 & 1 \\
\hline Abacaxi & 1 & 1 \\
\hline Caderno de laboratório & 1 por aluno & - \\
\hline Lápis de desenho & 1 por aluno & - \\
\hline Máquina fotográfica & 1 por grupo & - \\
\hline Medalhão de músculo bovino & 100 g por grupo & $500 \mathrm{~g}$ \\
\hline Amaciante de carne & 1 frasco por grupo & 4 \\
\hline Liquidificador & 1 por grupo & 5 \\
\hline Forno elétrico ou a gás & 1 & 1 \\
\hline Sal grosso & $\sim 4 \mathrm{~g}$ por grupo (adquira um pacote de 1 Kg e & $\sim 16 \mathrm{~g}$ \\
\hline Balança de precisão & divida as medidas entre os grupos) & \\
\hline
\end{tabular}

\section{Procedimento:}

1. Colocar a lâmina pronta sobre a pinça do microscópio e proceder, visualização do corte em aumento de 1000X (NÃO ESQUECER O ÓLEO DE IMERSÃO);

2. Com auxílio do Atlas de Histologia identificar a ultraestrutura proteica de actina e miosina do músculo estriado;

3. Desenhar a visualização;

Observe que ao término deste experimento os vinte minutos de inserção do medalhão a amostra já deve estar se esgotando, com isso, outros procedimentos serão ditados aos grupos participantes.

4. Retirar o medalhão de músculo das respectivas amostras e observar modificações estruturais, anotando-as e se possível fotografando-as para futuros relatórios da disciplina;

5. Com exceção do grupo "5", os demais devem proceder com sal grosso a salga do medalhão usando $3 \%$ do peso do medalhão em peso de sal, desta forma homogeneizando o preparo quanto a salga do material;

6. Levar ao forno elétrico em $180^{\circ} \mathrm{C}$ por vinte minutos para que o medalhão asse, a fim de preparar com ele a análise sensorial;

Enquanto o experimento II está sendo realizado (20 $\mathrm{min})$, deve-se iniciar o experimento III. 


\subsubsection{Experimento III}

Os alunos devem criar uma tabela de avaliação sensorial (Figura 1).

Material: Papel sulfite, régua, lápis e borracha.

\section{Procedimento:}

1. Criar uma tábua de avaliação sensorial que deve discriminar a maciez da carne, que o sujeito provara;

2. Convidar 20 alunos dos outros períodos para serem avaliadores na análise sensorial, entregando-Ihes a tabela avaliativa (Figura 1) e explicando aos mesmos como devem proceder;

É importante a realização das avaliações através da metodologia de ensaios controlados em que apenas os avaliadores (alunos que realizaram os experimentos e professores envolvidos na aula) saibam o que cada amostra contém, pois se comentários sobre o procedimento forem levantados, influenciaremos as respostas invalidando o procedimento.

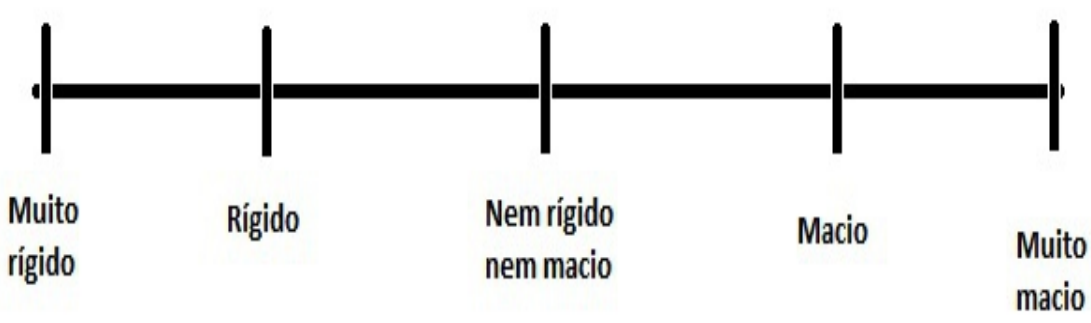

Figura 1.Modelo da tábua de avaliação sensorial construída pelos alunos.

\subsubsection{Análise sensorial}

Procedimento:

1. Retirar o medalhão do forno e dividi-lo em 20 pedaços uniformes;

2. Numerar uma bandeja de isopor de 1 a 6 ;

3. Dispor os preparados na bandeja na seguinte ordem. $1^{\circ}$ amaciante comercial, $2^{\circ}$ casca do abacaxi, $3^{\circ}$ poupa do abacaxi, $4^{\circ}$ casca do mamão, $5^{\circ}$ poupa do mamão e $6^{\circ}$ controle negativo;

4. Proceder à análise sensorial com os convidados. 


\subsubsection{Análise estatística}

Procedimento:

1. Tabular os dados obtidos na análise sensorial em softwares estatísticos (ex. Bioestat; Past; SAS 9.0, entre outros.);

2. Montar gráficos dos resultados para análise visual das diferenças entre os preparados;

3. Verificar se existe diferença significativa entre os dados usando testes estatísticos destinados a comparação entre tratamentos ou amostras diferentes com uma única amostragem (ex. testes de: Duncan; Tukey; Tost, entre outros.).

\section{Desenvolvimento}

\subsection{Prelúdio teórico}

As enzimas são moléculas extraordinárias que catalisam reações químicas, clivando e rompendo ligações covalentes nas células. Elas unem um ou mais ligantes, chamados substratos, e os convertem em metabólitos, os quais são produtos quimicamente modificados, fazendo isso muitas vezes, numa rapidez incrível [3]. Assim, as enzimas são responsáveis pela vida como a conhecemos, várias das reações necessárias a nossa existência demorariam muito tempo para ocorrer se não fossem catalisadas, a falta de catalisadores inviabilizaria a vida. Nesse sentido, Nelson e Cox [9] exemplificam que a Anidrase Carbônica (EC 4.2.1.1) presente na corrente sanguínea, é responsável pelo controle do $\mathrm{pH}$ do sangue através da catálise de dióxido de carbono e água em ácido carbônico, prótons e íons bicarbonato, e que ela acelera esta reação na ordem de $10^{7}$. As trocas gasosas seriam impossíveis se a velocidade de reação não fosse aumentada. Destaca-se a importância do estudo destas macromoléculas, e esta importância torna o estudo das enzimas, conteúdo obrigatório nos cursos de Bioquímica, e seus aspectos teóricos imprescindíveis ao entendimento dos processos vitais. Várias são as aulas necessárias para a incorporação do conteúdo e, desta forma, optou-se por trabalhar uma prática logo após a aula introdutória.

Antes de a prática ser efetuada os alunos tiveram contato na disciplina de Bioquímica com os conceitos fundamentais do funcionamento das enzimas, e.g. relação entre a especificidade enzimática e a velocidade da reação além de introduzir os 
conceitos de catálise enzimática, que ocorre porque a enzima aprisiona os substratos no seu sítio ativo criando um ambiente altamente favorável à reação. A abordagem foi teórica seguindo modelos (Figura 2) comumente presentes nos livros da disciplina. Para Justi [10], um modelo de ensino é um objeto ou situação que é trazido para o contexto de ensino a fim de ajudar os alunos a visualizarem o objeto ou a situação pretendida em suas mentes. A função de um modelo de ensino é fornecer suporte aos alunos a fim de que eles elaborem modelos mentais compreensíveis dos modelos consensuais.

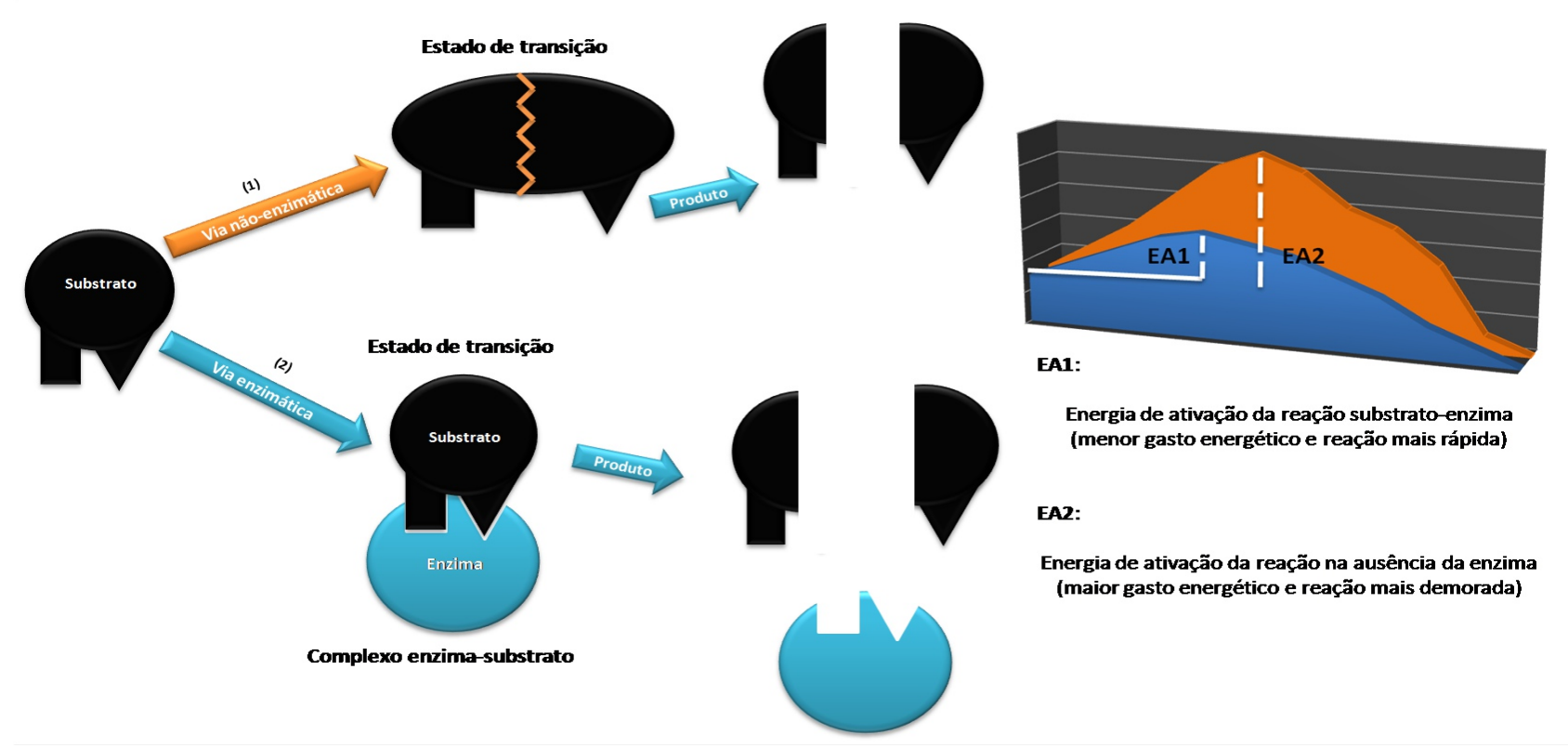

Figura 2. Modelos que representam a ação das enzimas, apresentados aos alunos em sala de aula.

Após a aula foram colhidos alguns relatos dos alunos, com o intuito de verificar o nível de compreensão alcançado pelos mesmos. Como exemplos dos relatos têm-se:

"Eu entendi professor! A bolinha se liga ao palitinho e quebra ele em dois" (ACADÊMICO 9).

Ou "Ô professor, o Pacmam come o quadradinho e ele, é dividido." (ACADÊMICO 6).

Ou ainda "Entendi sim professor, a enzima, pega o substrato, e quebra ele em dois". (ACADÊMICO 20).

Estes comentários revelam que os alunos não compreenderam o assunto, fizeram uma superficial visualização dos modelos e não o relacionam de uma forma mais profunda com o conteúdo.

\subsection{Relato da experiência}

Para realizar a prática foram necessárias quatro horas consecutivas da disciplina de Bioquímica ministrada para o curso de Nutrição. O espaço do laboratório e os 
equipamentos (balança de precisão e liquidificador) eram suficientes para que cada grupo realizasse seu procedimento sem aguardar o outro, o que facilitou com grande relevância a execução da prática. Neste momento poucas observações foram levantadas pelos alunos e as dúvidas se concentraram no aceite do ponto do homogeneizado pelos professores (Figura 3).

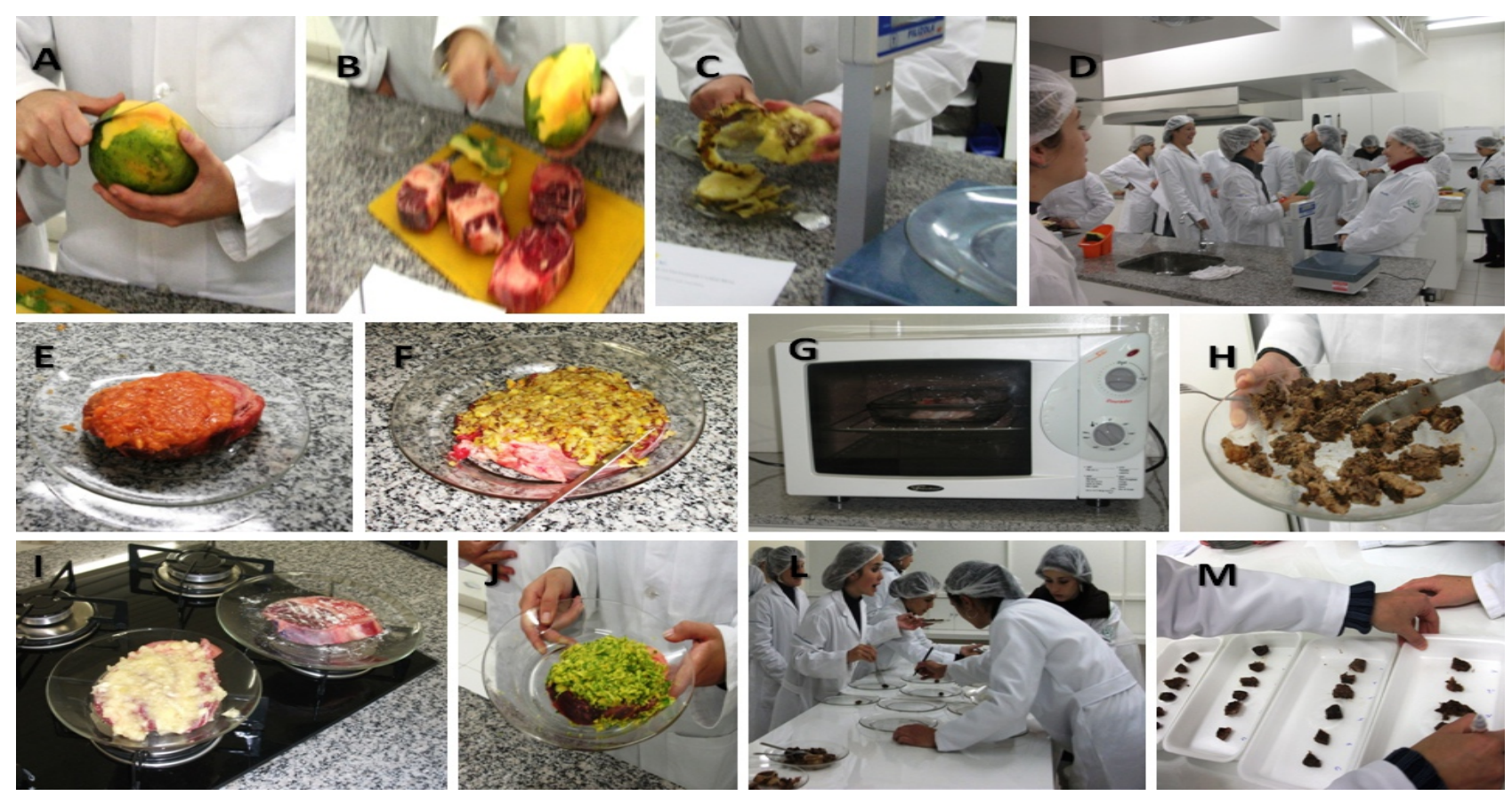

Figura 3. Fotos exemplificando as etapas da prática: A, B e C demonstram os alunos preparando seus homogeneizados; D demonstra o grupo de alunos nos momentos iniciais da prática; $\mathrm{E}, \mathrm{F}$, I e J demonstram os tratamentos em repouso; $\mathrm{G}$ demonstra o método de preparo; $\mathrm{H}$ e $\mathrm{M}$ demonstram a preparação para análise sensorial e $\mathrm{L}$ demonstra o comportamento dos alunos ao prepararem o material para a análise sensorial nas etapas finais da prática.

Concluída esta etapa, iniciou-se o procedimento dois, nesta etapa a curiosidade dos alunos começou a tomar forma e questionamentos sobre a ultraestrutura do músculo começaram a surgir através de perguntas como, por exemplo:

"Professor isto que eu estou vendo são as células do músculo?" (ACADÊMICO $15)$;

"Professor, o músculo é duro por causa destas estrias?" (ACADÊMICO 7);

"Mas o que é que o abacaxi vai fazer no músculo?" (ACADÊMICO 8).

Estas questões possibilitaram um enriquecimento do conteúdo de Biologia Celular, disciplina a qual vestes alunos também estavam cursando neste período, possibilitando um fortalecimento dos conceitos de proteínas e de suas funções. Exemplificando o trabalho das miosinas, tropo miosinas e actinas na contração muscular (Figura 4), foi possível esclarecer as características do tecido muscular, e da ação das enzimas proteolíticas na quebra destas interações. 

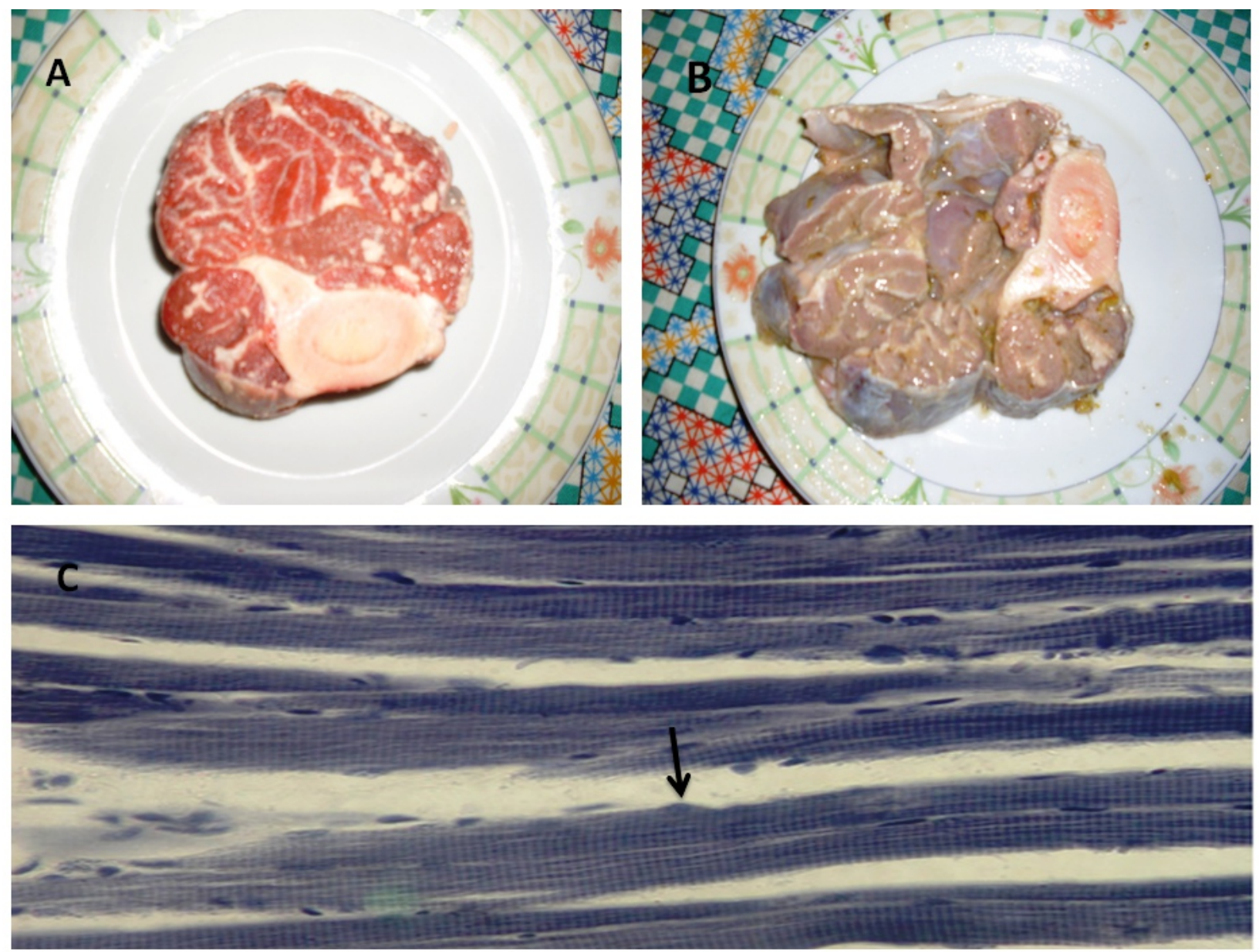

Figura 4. Fotos demonstrando o experimento 2: $A$ e $B$ demonstram o medalhão de músculo antes(A) e depois (B) de entrarem em contato por meia hora com o homogeneizado de casca de Abacaxi; C demonstra a lâmina histológica de músculo preparada com a técnica de Hematoxilina Férrica, na seta detalhe das microfibrilas de actina e miosina (aumento de 400X).

Realizada esta etapa os alunos se mostraram muito empolgados, questionavam como deveria estar o músculo e levantavam hipóteses da textura que encontrariam após este período de espera.

Após o retorno, expressões de surpresa e iniciativas próprias de comparar os resultados entre os grupos foram observadas. Realmente o aspecto visual dos medalhões de músculo revelou a ação das enzimas proteolíticas e, é possível notar diferenças claras entre os tratamentos (Figura 4). Neste momento, os professores devem explicar como as enzimas realizam o fenômeno catalítico observado.

Na tentativa de evitar o empirismo e para dar noção científica aos alunos, realizouse o procedimento III seguido de uma breve revisão sobre conceitos de análise sensorial e validação da metodologia, o que aguça ainda mais a curiosidade dos acadêmicos. 
O procedimento escolhido foi o teste de ordenação [11] onde se avalia se há diferenças entre duas ou mais amostras.

O procedimento IV iniciou-se após o término do tempo destinado para assar os medalhões de músculos que receberam os tratamentos. Os alunos mostraram-se muito preocupados em realizar o procedimento de forma mais acertada possível, percebeu-se neles muita seriedade com relação à prática e ao cuidado com os provadores. Foi possível observar que a postura tomada por eles foi à de realizadores de um experimento, ao qual instigava conhecer as respostas, como exemplo disto, pode-se citar o comportamento dos responsáveis por guardar as fichas de avaliação, pois estes foram enumerando os resultados durante a análise, tendo os valores certos ao final do mesmo.

A análise estatística foi realizada durante a aula de Bioestatística dos alunos (figura 5), e os resultados das análises foram relatados na segunda aula de Bioquímica destinada ao estudo das enzimas.

\section{Estatísticas descritivas (Dados quantitativos):}

\begin{tabular}{l|r|r|r|r|r|r|}
\hline \multicolumn{1}{|c|}{ Estatistica } & Poupa do mamão & Casca do mamão & Poupa do abacaxi & Casca do abacaxi & amaciante comercial & controle \\
\hline No. de observações & 5 & 5 & 5 & 5 & 5 & 5 \\
\hline Mínimo & 2,000 & 0,000 & 0,000 & 0,000 & 0,000 & 0,000 \\
\hline Máximo & 14,000 & 18,000 & 14,000 & 20,000 & 18,000 & 20,000 \\
\hline $1^{\circ}$ Quartil & 3,000 & 1,000 & 1,000 & 0,000 & 2,000 & 0,000 \\
\hline Mediana & 5,000 & 3,000 & 7,000 & 2,000 & 5,000 & 0,000 \\
\hline $3^{\circ}$ Quartil & 6,000 & 8,000 & 8,000 & 10,000 & 5,000 & 10,000 \\
\hline Média & 6,000 & 6,000 & 6,000 & 6,400 & 6,000 & 6,000 \\
\hline Variância (n-1) & 22,500 & 54,500 & 32,500 & 74,800 & 49,500 & 80,000 \\
\hline Desvio-padrão (n-1) & 4,743 & 7,382 & 5,701 & 8,649 & 7,036 & 8,944 \\
\hline
\end{tabular}

Comparações múltiplas pareadas utilizando o procedimento de Duncan:

\begin{tabular}{lc|c}
\hline \multicolumn{1}{c|}{ Amostra } & Soma das ordenações & Grupos \\
\hline 2 | Casca do mamão & 2,000 & a \\
\hline 2 | Poupa do abacaxi & 2,000 & $a$ \\
\hline 2 | Casca do abacaxi & 2,000 & a \\
\hline 2 | amaciante comercial & 4,000 & b1 \\
\hline 2 | controle & 5,000 & b2 \\
\hline
\end{tabular}

Figura 5. Exemplo de alguns resultados obtidos pelos alunos na análise estatística: acima análise descritiva da amostra, abaixo teste de comparação.

Neste momento foi novamente questionado aos alunos sobre o que eles haviam aprendido sobre a aula e exemplos das respostas são os que seguem:

“A bromelina e a papaína são enzimas que degradam proteínas, elas estão mais presentes na casca do que na poupa do fruto e elas amaciam as carnes 
quebrando as ligações entre a actina e a miosina e como é mesmo o nome daquela outra". (ACADÊMICO 2).

$\mathrm{Ou}$ "As enzimas aceleram as reações e modificam as coisas, por exemplo, a enzima do mamão que degradou a carne com somente 20 minutos". (ACADÊMICO 6).

Ou ainda "Nós aprendemos como faz a análise sensorial, e o resultado deu que a bromelina é mais forte que a papaína e que tem mais bromelina na casca que na poupa". (ACADÊMICO 10).

As respostas, de modo geral, foram direcionadas pelo que os alunos viram na prática e pelas suas analogias do que observaram, e embora as respostas ainda fossem muito intuitivas, e pouco teóricas elas demonstraram um ancoramento do conhecimento que a eles está sendo transmitido, em uma realidade por eles vivenciada.

\subsection{Observações gerais}

Silva [6] ao analisar os planos de ensino da disciplina de Bioquímica no contexto dos cursos da saúde verificou que a inserção curricular se dá no ciclo básico de formação, e que ela tem um enfoque intradisciplinar, para a autora existe uma tendência à homogeneização dos objetivos centrando o ensino no que ela chama de "saber bioquímico", frequentemente não contextualizado à proposta específica de formação profissional. Nossa experiência revelou que quando trabalhamos a disciplina neste contexto fora da proposta de formação profissional, ela torna-se penosa aos alunos e de difícil compreensão, a experiência desta aula prática interdisciplinar, nos mostrou que a disciplina passa a ser considerada agradável quando passa a ser percebida como fator prolífero para a vida profissional. Falcão [13] relata que o método pedagógico seguido da "redescoberta" é entendido como uma forma de levar os alunos a adquirirem conhecimentos ao mesmo tempo em que "redescobrem" o caminho científico produtor deste mesmo conhecimento. Percebemos nesta experiência que quando usamos a pedagogia da redescoberta instigamos não só o conhecer, mas o explorar, e o contestar por parte dos alunos.

Nenhum saber se forma sem um sistema de comunicação, de registro, de acumulação, de deslocamento [14-15]. Quando conseguimos levar o aluno a praticar estes três pré-requisitos, como acreditamos ter feito nesta experiência, realmente se faz a nosso ver o ensino aprendizagem, pois vamos além da simples transferência de informações.

$\mathrm{Na}$ disciplina de Bioquímica e nas disciplinas a ela relacionadas, existe uma 
necessidade dos alunos de perceber enquanto algo tangível o porquê das reações e o como elas acontecem, e esta necessidade não é suprida pela apresentação de modelos.

Os experimentos apresentam uma alternativa didática, pois associam métodos laboratoriais a temas cotidianos [16].

Para Loguercio e Del Pino, [17] "O enunciado é um átomo do discurso e só é possível de ser entendido quando em um campo enunciativo em que apareça como elemento singular" (o grifo é nosso). A associação passa a ser algo necessário ao ensino, como relata Foucault "Não basta dizer uma frase,... para que se trate de um enunciado: é preciso relacioná-la com todo um campo adjacente" [18].

Esta realidade do ensino da Bioquímica enquanto necessariamente interdisciplinar não nos é particular, Loguercio [19] estudando ciênciometria da educação em Bioquímica relata os seguintes títulos de abstracts:

"- Ensinando Bioquímica: uma aproximação à orientação de projetos (TITULO 1);

- Redescobrindo os fatos: as vantagens do uso de curtos projetos de pesquisa nas aulas de laboratório de Bioquímica Básica (TITULO 2);

- Bioquímica da Água: uma aproximação multidisciplinar (TITULO 3);

- Ensinando Biologia Molecular por um processo formativo (TITULO 4);

-Ensinando Bioquímica usando interdisciplinaridade e aspectos multidisciplinares (TITULO 5);

- Dois casos clínicos para ensinar corpos cetônicos na PBL - como estratégia" (TITULO 6).

Pode-se perceber pelos títulos que existe uma necessidade de tentar aproximar os alunos dos aspectos tangíveis da disciplina, como observado nos títulos 1, 2 e 6, em que os autores relatam experiências com a pedagogia da redescoberta, percebemos ainda nos títulos 3 e 5 que a visão tende a interdisciplinaridade, contexto a nosso ver lógico para o ensino da Bioquímica, e percebemos ainda pelo título 4 que a pedagogia da redescoberta por si só sem um pressuposto teórico onde os alunos possam ancorar suas hipóteses, não parece efetiva, pois se torna informal.

Fernandes e Neto, [8] ao analisarem teses e dissertações com práticas do modelo da redescoberta, argumentam que a relação professor-aluno se deu de forma vertical, nas três pesquisas por eles analisadas, já que "era a professora quem decidia sobre o andamento das aulas, e as atividades que deveriam ser realizadas".

Essa verticalização em bioquímica não é uma necessidade pedagógica, no entanto são necessários conhecimentos específicos prévios para a real compreensão dos conteúdos avançados. Nesse sentido o direcionamento das aulas deve ser dado pelo docente, pois este é o responsável pela condução dos alunos na tomada de 
conhecimento. No entanto, a internalização do conhecimento pelo aluno é particular e intrínseco às suas vivências e experiências particulares, quando possibilitamos ao aluno vivenciar a descoberta científica, tão somente estamos dando ao aluno a possibilidade de internalizar e assimilar o conhecimento que a princípio para ele era apenas abstração.

\section{Considerações finais}

Ao retomarmos a pedagogia da redescoberta, como técnica pedagógica dentro de uma perspectiva interdisciplinar, observamos o quão relevante é para o aluno esta prática e percebemos que se não houver fatores limitantes, como recursos financeiros e ou equipamentos a pedagogia da redescoberta é frutífera e eficaz para o ensino.

Embora a pedagogia da redescoberta seja direcionada à repetição de experimentos, existe uma relação professor-aluno que vai além da simples transferência vertical de conhecimento, pois ao realizar a prática o aluno instintivamente gera hipóteses para suas observações e gera relações entre o observado e o conteúdo básico da disciplina, cabe ao professor não ignorar as observações de seus alunos, mas partir destas, para instigar a busca da real compreensão do que foi estudado.

\section{REFERÊNCIAS}

[1] Marzzoco A,Torres BB. Bioquímica Básica 20 ed. Rio de Janeiro, Guanabara Koogan. 1999.

[2] Pinheiro T M L, da Silva JÁ, Moraes de Souza PR., Nascimento M M.do,

Oliveira HD de. Ensino de Bioquímica para acadêmicos de Fisioterapia: Visão e avaliação do discente. Revista Brasileira de Ensino de Bioquímica e Biologia molecular 2009; 09(1): $1-11$.

[3] Alberts B, Bray D, Lewis J, Raff M, Roberts K, WatsonJ. Molecular Biology of the Cell. 3 ed. New York: Garland. 2004.

[4] Devlin TM. Manual de Bioquímica com correlações clínicas, 6. Ed. Editora Blucher, São Paulo. 2007.

[5] Murray RK, Granner DK, Mayes P A, Rodwell V. Bioquímica de Harper Ed. Atheneu . 26 ed. 1997.

[6] Voet D, Voet J. Bioquímica. 3. ed. Porto Alegre: Artmed, 2000.

[7] Freire P. Essa escola chamada vida: depoimentos ao repórter Ricardo Kotscho. 14. ed. São Paulo: (Série educação em ação). Ática , 2004.

[8] Fernandes RCA, Neto JM. Modelos educacionais nas pesquisas sobre práticas 
pedagógicas no ensino de ciências nos anos iniciais da escolarização (1972-2005) In Anais do XII Encontro nacional de pesquisa em Educação em Ciência- Enpec, 8 de novembro de 2009, Florianópolis, SC. ENPEC. 2009. p1-11.

[9] Nelson DL, Cox M, Lehninger M. Princípios de Bioquímica. 4 ed. Sarvier. 2006.

[10] Justi RS. Models in the Teaching of Chemical Kinetics. Unpublished PhD Thesis. Reading: The University of Reading. 1997.

[11] Barboza LMV, Freitas RJS, Waszcznskyj N. Desenvolvimento de produtos e análise sensorial. Brasil alimentos, v. 18. 2003.

[12] Silva IF da. O ensino de Bioquímica na graduação em saúde: uma análise. Tese: Apresentada a Universidade Federal de São Paulo. Escola Paulista de Medicina. (Curso de Biologia Molecular para obtenção do grau de Doutor). 2002.

[13] Falcão, E.B. de M. Uma experiência de ensino centrada na formação do pensamento científico do estudante. Revista Brasileira de educação médica.1985. 9(3):147-53.

[14] Gouveia M. Ensino de Ciências e Formação Continuada de Professores: algumas considerações históricas. Educação e Filosofia, 1995.17(1):227-257.

[15] Loguercio R. Conhecimentos Implícitos e Interesses dos Alunos na Construção de um Currículo para a 8a. Série da Escola Básica. Porto Alegre: Curso de Pós-Graduação em Ciências biológicas: Bioquímica, Instituto de Ciências Básicas e da Saúde. Dissertação de Mestrado. 1999.

[16] Lima SLT, Jesus MB, Sousa RRR, Okamoto AK, LimaR, FracetoLF. Estudo da atividade proteolítica de enzimas presentes em frutos. Química Nova na Escola, 2008. 28: 47-49.

[17] Loguercio R, Del Pino JC. Os Discursos Produtores da Identidade Docente. Ciência e Educação, 2003. 9(1): 17-26.

[18] Foucault M. Ditos e Escritos II, arqueologia das ciências e história do pensamento. Org. Manoel Barros da Motta, Forense Universitária, Rio de janeiro, 2000.

[19] Loguercio R, Souza D, Del Pino JC. Educação em Bioquímica: Um programa disciplinar. Revista Brasileira de Pesquisa em Educação em Ciências, Bauru/SP, 2003. 3, (2): 30-44. 